\title{
Seasonal Occurrence and Aggregation Behavior of the Sea Urchin Astropyga pulvinata (Echinodermata: Echinoidea) in Bahía Culebra, Costa Rica ${ }^{1}$
}

\author{
Fuan Fosé Alvarado²
}

\begin{abstract}
Between October 2003 and July 2005, aggregation behavior of the sea urchin Astropyga pulvinta Lamarck was studied in Bahía Culebra, Costa Rica. This sea urchin forms aggregations during part of the year and then disappears. I quantified the number of individuals present in a defined area each month, their aggregation behavior between day and night, and their size. Also, temperature and nutrient concentrations of the water were sampled. There were significantly more individuals in aggregations during the colder, upwelling season (December to April). Aggregations consisted of adult individuals that exploit food during the upwelling season. Moreover, these aggregations were used as a refuge by several fish species of high commercial value for the aquarium trade. These sea urchin populations could suffer as extraction of ornamental fishes and urchins increases. Their abundance and behavior should continue to be monitored as an indication of the ecological health of the community.
\end{abstract}

Diadematid SEa urchins are among the most important and familiar inhabitants of tropical and subtropical waters (Hyman 1955). Their ability to occupy different niches is an important factor in their success; they live on coral reefs, mangrove roots, sea grasses, and sand flats. Moreover, their success is linked to their generalist diet and their efficiency in use of the resources available. They are found in caves, overhangs, and crevices that provide protection against predators, and they are more abundant in zones protected from strong waves. For that reason, if wave stress increases, or if predators or competitors are present, diadematids tend to aggregate. They play an important role on

\footnotetext{
${ }^{1}$ Support was provided by Vicerrectoría de Investigación of the Universidad de Costa Rica, for partial financial support through the projects of Jorge Cortés 80896-601 and 808-98-013 and Ecodesarrollo Papagayo. Manuscript accepted 14 December 2007.

${ }^{2}$ Centro de Investigación en Ciencias del Mar y Limnología (CIMAR), Universidad de Costa Rica (UCR), 2060 San Pedro, San José, Costa Rica (e-mail: juanalva76@yahoo.com).
}

Pacific Science (2008), vol. 62, no. 4:579-592

(C) 2008 by University of Hawai'i Press

All rights reserved reef areas due to their substantial effects on the biomass, structure, and distribution of seaweeds, as well as on coral composition and reef geomorphology because they are bioeroders (see review by Birkeland 1989).

In the eastern tropical Pacific there are five diadematid species in four genera: Astropyga, Centrostephanus, Echinothrix, and Diadema. The last genus has received more attention in the eastern Pacific due to the important role of Diadema mexicanum as a reef bioeroder and controller of seaweed populations (Glynn 1988, Guzmán 1988, Fischer 1990, Guzmán and Cortés 1992, 2007, HerreraEscalante et al. 2005). Also, its reproductive cycle and population structure (Lessios 1981, Espino-Barr et al. 1996) have been studied, as well as its phylogeographic relationships (Lessios et al. 2001). With respect to Centrostephanus coronatus, its bioerosional impact (Toro-Farmer et al. 2004), role in controlling algae (Vance 1979), and reproductive cycle (Kennedy and Pearse 1975) have been studied. But there are very few papers on Echinothrix and Astropyga in the eastern Pacific.

Members of the genus Astropyga are among the most conspicuous diadematids, with a series of iridescent blue spots on the test, thin spines, and a large, flexible, and very low test (Mortensen 1940, Caso 1978). 
Astropyga is found in tropical and subtropical waters of the Caribbean, Indo-Pacific, and eastern Pacific and includes three species (Mortensen 1940): A. magnifyca, A. radiata, and A. pulvinata. Astropyga pulvinata Lamarck has been reported from the Gulf of California (Solís-Marín et al. 2005), El Salvador (Barraza and Hasbún 2005), Panamá (Lessios 2005), Colombia (Neira and Cantera 2005), the Galápagos Islands (Hickman 1998), and Lobos de Afuera Island in Perú (Hooker et al. 2005). It occurs on sand, rock, or muddy substrates (Clark 1940, Caso 1978, Hickman 1998) between 2 and $95 \mathrm{~m}$ deep (Clark 1948, Hickman 1998; C. Fernández, pers. comm.). It possesses a flat test with triangular white areas on the interambulacral zones (Mortensen 1940) and a maximum test diameter of $120 \mathrm{~mm}$ (Brusca 1980). This species eats any kind of bottom material with foraminifera and small gastropods (Mortensen 1940, De Ridder and Lawrence 1982). In several sections of the American coast, large aggregations of this sea urchin have been observed, generally during the upwelling season, but they later disappear (Hickman 1998, Hooker et al. 2005, Lessios 2005).

Diadematid aggregations have been observed in many places around the world, like the Great Barrier Reef of Australia, in Japan, Suez, in the Caribbean, and in the eastern Pacific (see references in Pearse and Arch [1969]). In Huatulco Bay, on the Pacific coast of Mexico, aggregations of Diadema mexicanum composed of hundreds of individuals caused intense grazing on a dead reef of Pocillopora (Glynn and Leyte-Morales 1997). Aggregations of Astropyga pulvinata have been observed in several localities in the eastern Pacific: in the Galápagos Islands (Albany Island) aggregations of two to $\sim 300$ individuals in depths around $12 \mathrm{~m}$ appear in February and disappear in November (Hickman 1998). Aggregations have been observed sporadically during some times of the year on Cocos Island, and then they disappear suddenly ( $\mathrm{N}$. Gersinich, pers. comm.). In Panamá, during the upwelling season, they can be found in great concentrations in the Gulf of Panamá (Changame Island), over sand at approximately $10 \mathrm{~m}$ depth (Lessios 2005). At Lobos de Afuera Island, Perú, they formed numerous aggregations on rocky reef between 0 and $5 \mathrm{~m}$ deep in June 1999 (Hooker et al. 2005).

The objective of this work is to describe basic ecological characteristics of Astropyga pulvinata in Bahía Culebra, on the northern Pacific coast of Costa Rica. Abundance, density, degree of aggregation, and population structure are described as well as their relation to several physicochemical parameters, with the goal of determining the spatial and temporal extent of aggregations and which parameters might control them.

\section{MATERIALS AND METHODS}

The study took place between October 2003 and July 2005, at Punta Flor (10 37' 26.80" $\mathrm{N}, 85^{\circ} 40^{\prime} 45.4^{\prime \prime} \mathrm{W}$ ) (Figure 1) in the inner part of Bahía Culebra on the north Pacific coast of Costa Rica. This bay is subjected to a seasonal upwelling of cool, rich waters between December and April (Brenes et al. 1990, Jiménez 2001). It consists of a series of inlets, beaches, sea cliffs, and estuaries with economically important marine resources (Jiménez 2001). It is a zone rich in coral reefs, with approximately 16 species of reefbuilding corals, and live coral cover of $44 \%$ (Jiménez 2001). Punta Flor is located on the inner part of the bay, in the north section. It is a zone surrounded by sea cliffs with scarce vegetation, a narrow intertidal zone, and a sea bottom composed mainly of coarse and medium sand (C. Fernández, unpubl. data).

\section{Biological Variables}

Astropyga pulvinata is a common sea urchin in Bahía Culebra that in some periods of the year forms aggregations (two or more individuals close together, touching at least by their spines) (Figure 2). With the goal of understanding this behavior, the dynamics of the aggregations were studied between October 2003 and July 2005 in Punta Flor (Figure 1). The monthly density of the sea urchin and the aggregation behavior between day and night were determined by measuring the distance between individuals. To determine 


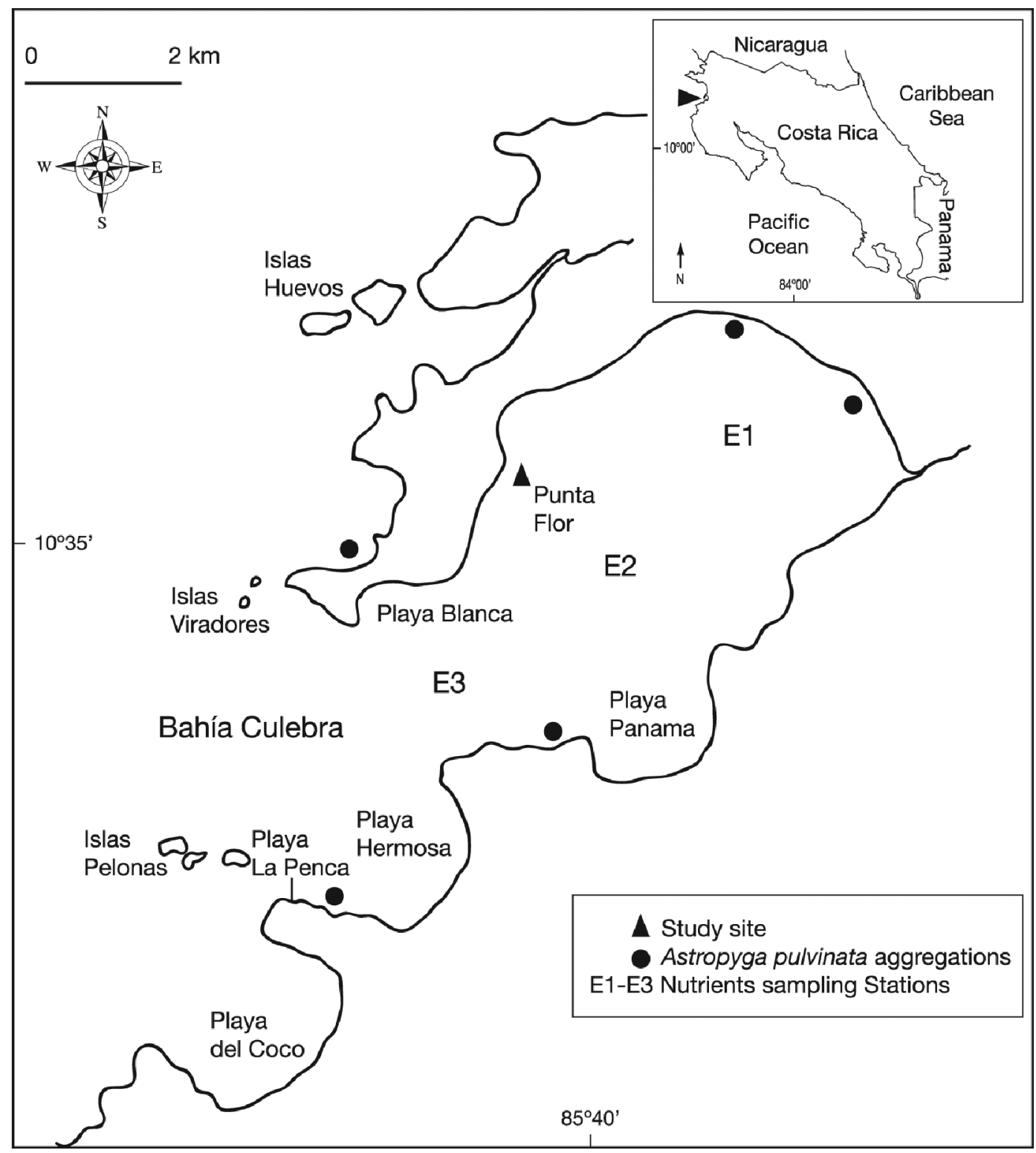

Figure 1. Punta Flor location in Bahía Culebra, sites where Astropyga pulvinata aggregations occur, and nutrient sampling stations inside the bay.

abundance, all individuals of the sea urchin were counted monthly in an area of 3,125 $\mathrm{m}^{2}$ (125 $\mathrm{m}$ long by $25 \mathrm{~m}$ wide). The area was covered in a zigzag manner from around $2 \mathrm{~m}$ depth down to 8-10 m (approximately $25 \mathrm{~m}$ from the coastline), counting all the aggrega- tions and the number of sea urchins per aggregation. The sampling always took place between 0800 and 1000 hours. Between November 2003 and February 2004 night dives were done, between 1830 and 2000 hours, to observe the nocturnal aggregation behavior. 


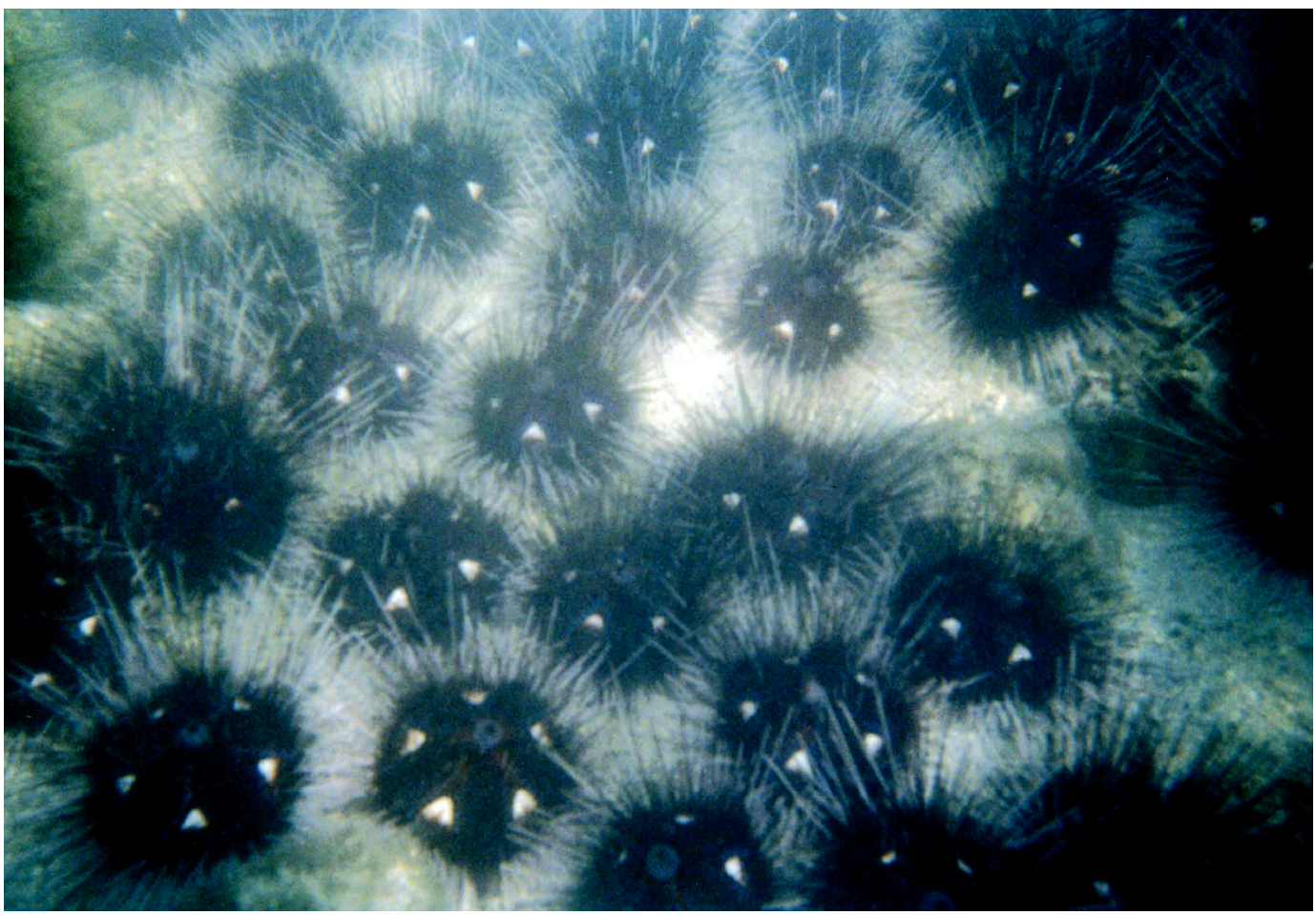

Figure 2. Astropyga pulvinata adult aggregation at Punta Flor, Bahía Culebra.

The diameter of the test was measured, between November 2003 and September 2004 with a caliper, to define population structure over time. Ten individuals were measured per aggregation, so the total number measured depended on the number of aggregations during the sampling dive. This procedure followed the same zigzag pattern, always measuring and counting the urchins in the same direction to avoid counting the same individuals twice.

Finally, between January and February 2004, the distance between individuals was measured with a metric tape from the border of the test of the urchin to the nearest neighbor test, during the day and night, to determine if there is a higher or lower degree of aggregation depending on the time of the day. We counted a minimum of 50 individuals per dive. The results are presented as averages \pm the standard deviation.

Nonparametric Kruskal-Wallis tests were done to determine if there were differences between: (a) the total number of individuals per month (or density) and the season of the year (upwelling and nonupwelling); (b) the distance between individuals and the time of day; (c) the number of aggregations and the time of day; (d) the total number of individuals per sampling and the time of day; and (e) the average of individuals per aggregation and the time of day.

\section{Physicochemical Variables}

As part of a Centro de Investigación en Ciencias del Mar y Limnología (CIMAR) monitoring program, seawater temperature was recorded every $30 \mathrm{~min}$ with a data logger (StowAway) located at $6 \mathrm{~m}$ depth on the Playa Blanca reef (Figure 1). The concentration of phosphate $\left(\mathrm{PO}_{4}^{-3}\right)$ at three stations in the bay (E1, E2, E3) (Figure 1) was determined as a proxy of the productivity of the environment. 


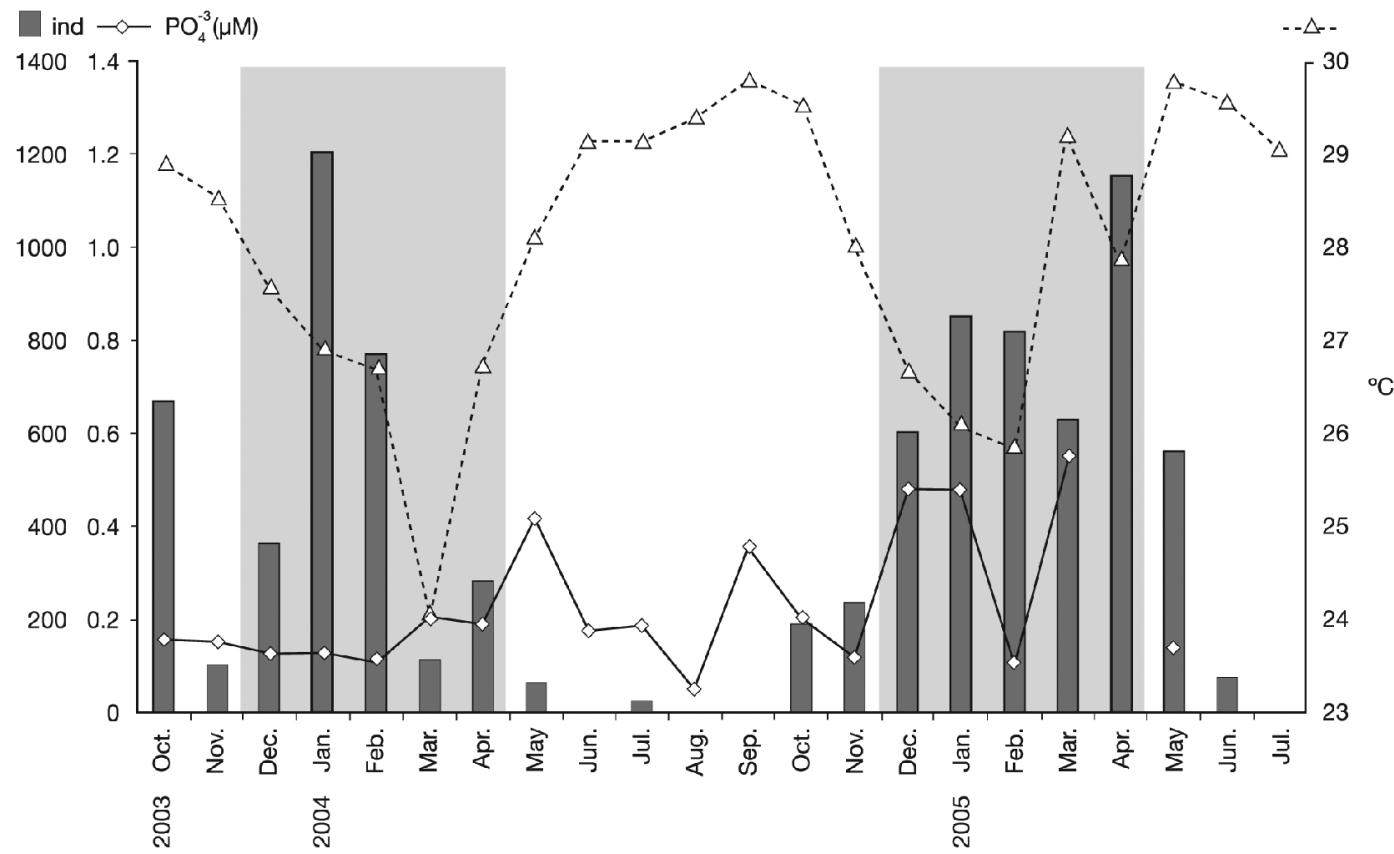

FIgURE 3. Total individuals of Astropyga pulvinata observed per month (columns), monthly average seawater temperature $\left({ }^{\circ} \mathrm{C}\right.$, open triangles), and average phosphorus concentration $(\mu \mathrm{M}$, open diamonds) at Punta Flor, Bahía Culebra. No phosphorus determinations were available for April, June, and July 2005. The upwelling season is indicated by gray shading.

Every month at each station, 1 liter of surface water was sampled and later analyzed following the procedures of Strickland and Parsons (1972) using a spectrophotometer (Shimadzu UV-160A).

Linear regressions between monthly average temperature and nutrient concentrations, and total numbers of individuals per month were done. All the data were transformed with the function $\log _{10}(x+1)$ and analyzed with the programs Systat 8.0 (Systat Software 1998) and JMPin 4.0 (SAS Institute 2001).

\section{RESULTS}

\section{Physicochemical Variables}

During the study period, the average sea temperature was $27.8 \pm 1.57^{\circ} \mathrm{C}$, being maximal in September $2004\left(29.8^{\circ} \mathrm{C}\right)$ and minimal in March $2004\left(24.1^{\circ} \mathrm{C}\right)$, corresponding with the rainy and the dry (upwelling) season, respectively (Figure 3 ). The average phospho- rus concentration was $0.23 \pm 0.15 \mu \mathrm{M}$, with a maximum value of $0.56 \mu \bar{M}$ in March 2005 and a minimum of $0.05 \mu \mathrm{M}$ in August 2004 . Phosphate followed a pattern opposite to that of temperature, with high values during the dry season (upwelling) (Figure 3).

\section{Biological Variables}

Astropyga pulvinata was more abundant during the upwelling season and almost absent in the nonupwelling season (Figure 3). An average of $679 \pm 356$ individuals per month was calculated for the upwelling season and $159 \pm 226$ individuals per month for the nonupwelling season. It was most abundant in January 2004 (1,203 individuals) and absent in June, August, and September 2004 (Figure 3). A significant difference was detected among seasons between the numbers of individuals (dry versus rainy season) $(\mathrm{KW}=10.0$, $P<.01, n=22)$. No relationship was detected between the concentrations of phos- 

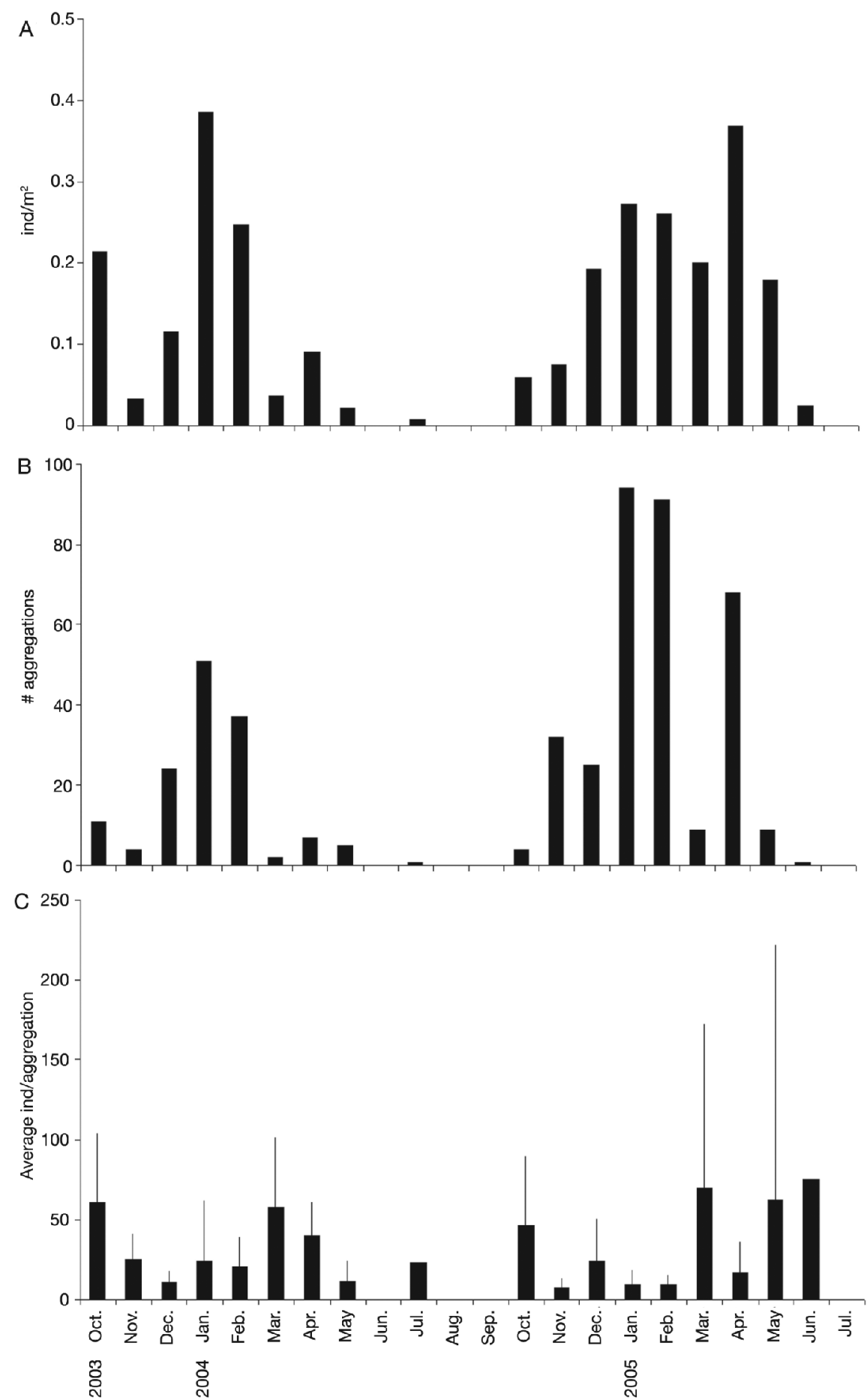

FIgURE 4. ( $A$ ) Density (individuals per square meter), $(B)$ number of aggregations, and $(C)$ average and standard deviation of individuals per aggregation of Astropyga pulvinata at Punta Flor, Bahía Culebra, between October 2003 and October 2005. 
A

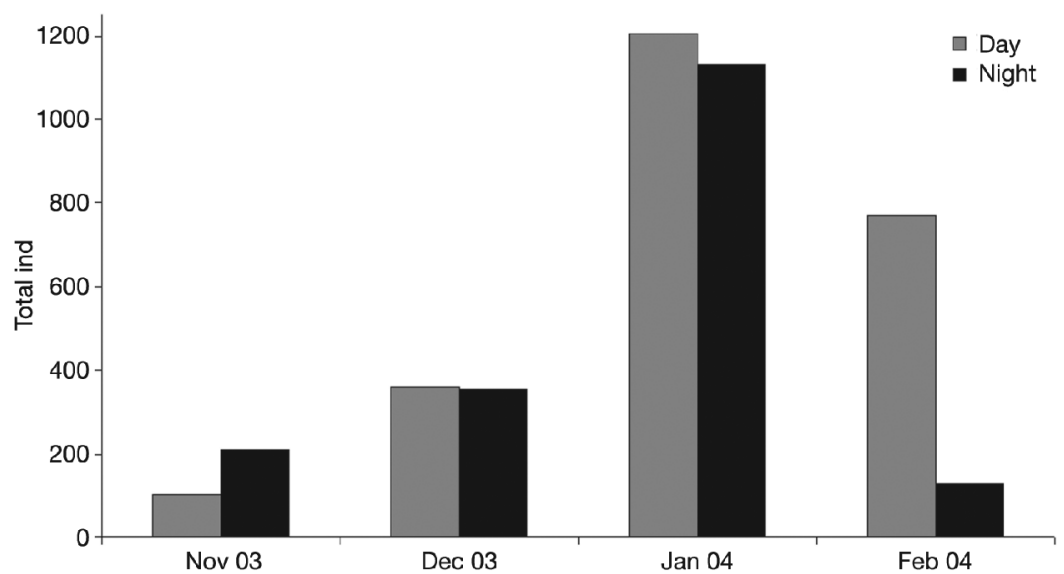

B

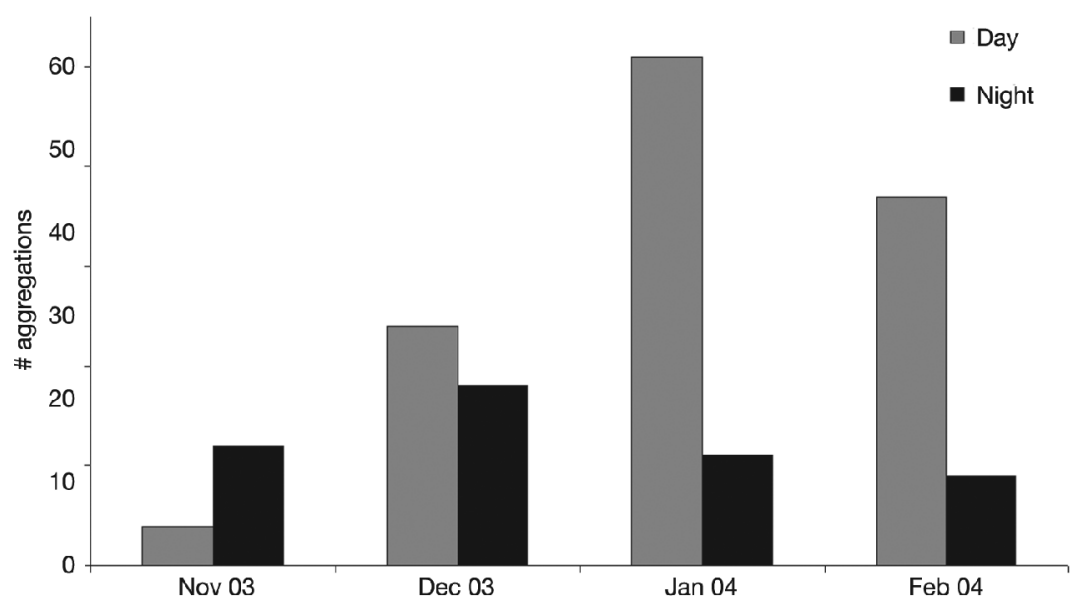

C

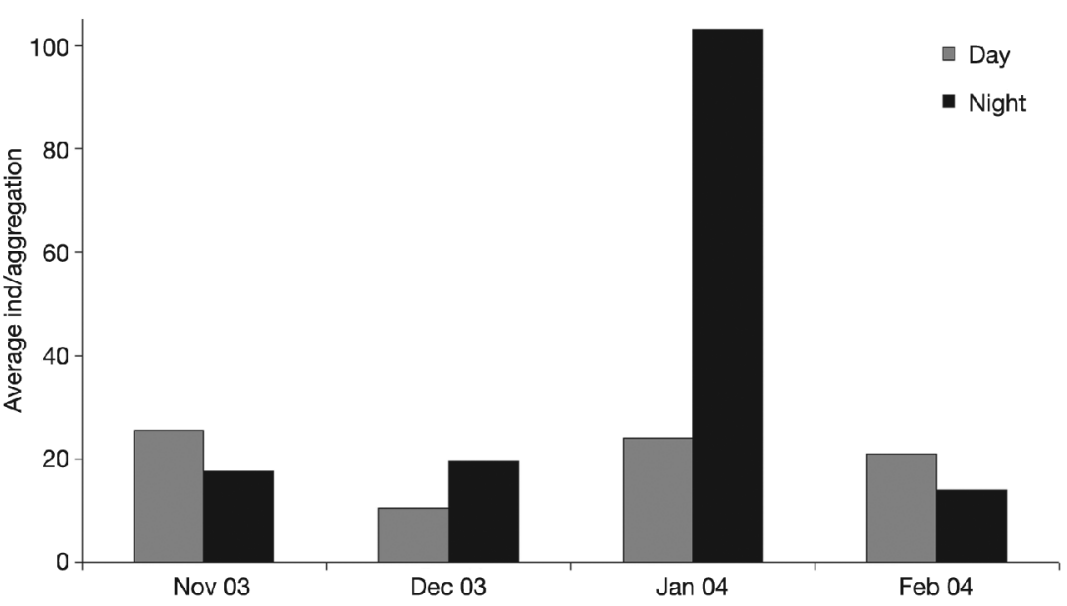

Figure 5. Comparison of aggregations of Astropyga pulvinata at Punta Flor, Bahía Culebra, between day and night from November 2003 to February 2004. (A) Total individuals, $(B)$ number of aggregations, and $(C)$ average number of indviduals per aggregation. 


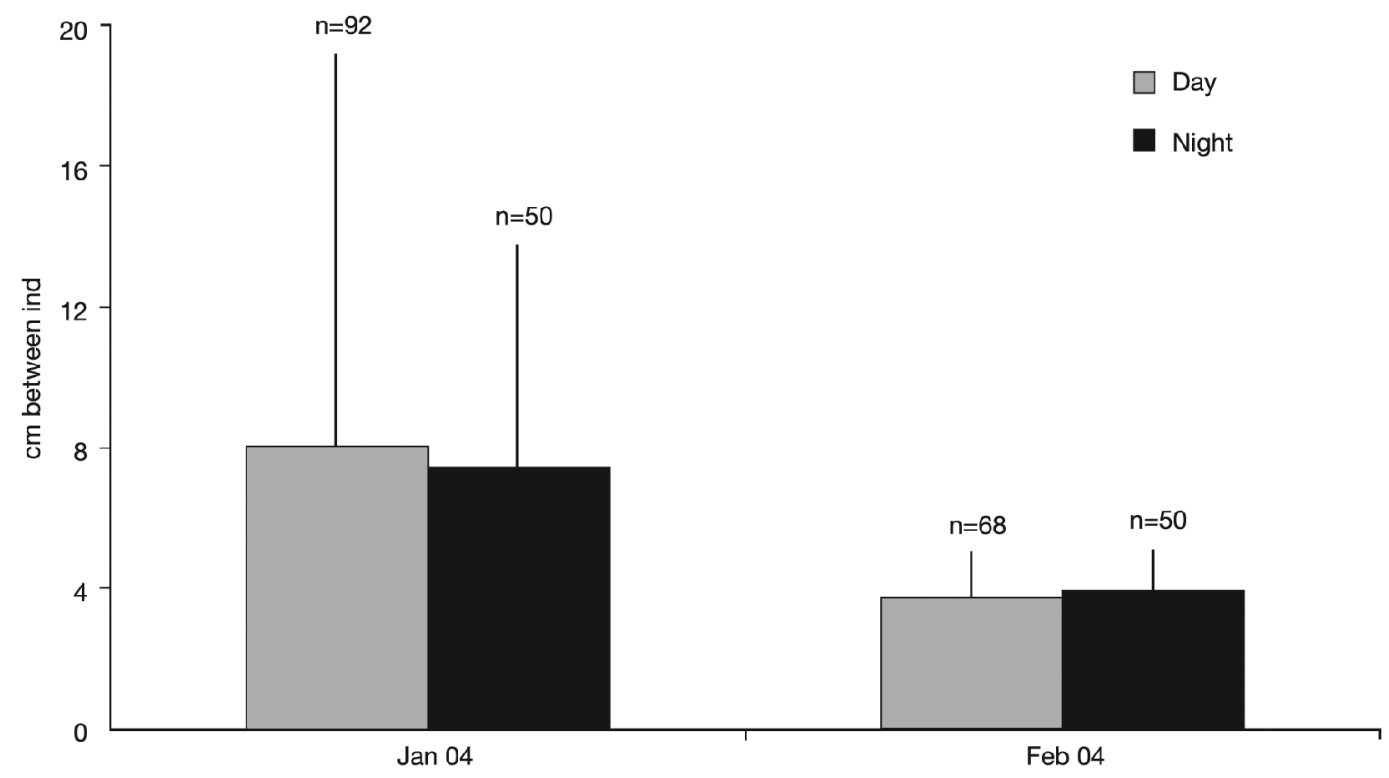

Figure 6. Average distance (centimeters) and standard deviation between individuals of Astropyga pulvinata in day and night aggregations at Punta Flor, Bahía Culebra, January and February 2004.

phate and the quantity of individuals per month, but there was a significant negative relationship with temperature $\left(R^{2}=0.21\right.$, $P<.05)$.

The average density was $0.13 \pm 0.12$ individuals per square meter, $0.2 \pm 0.1$ individuals per square meter for the upwelling season, and $0.1 \pm 0.1$ individuals per square meter for the nonupwelling season, with two maximal values of 0.38 and 0.37 individuals per square meter for January 2004 and April 2005 , respectively (Figure $4 A$ ). The highest numbers of aggregations between 0800 and 1000 hours were observed in January, February, and April 2004 with 94, 91, and 68 aggregations per month, respectively (Figure $4 B$ ), and an average of $21.6 \pm 29.3$ aggregations per month, $40.8 \pm 34$ aggregations per month for the upwelling season, and $5.6 \pm 9.1$ aggregations per month for the nonupwelling season. On average each aggregation had $26.9 \pm 24.5$ individuals. June 2005 (a nonupwelling month) was the month with the highest number of individuals per aggregation (75), followed by March 2005 (69.7) (Figure $4 C$ ). In June 2005 there was only one aggregation, and in March 2005 there were nine aggregations with a total of 559 individuals. January 2004, with 24 individuals per aggregation, was the month with the highest number of individuals $(1,203)$.

There was no statistical difference between the average number of individuals during the day $(610 \pm 482)$ and during the night $(457 \pm 460)(\bar{P}=.56)$. There were also no statistical differences between average numbers of aggregations during the day $(29.0 \pm 20)$ and at night $(12.5 \pm 3.9)$, or between average number of individuals per aggregation in the night $(38.6 \pm 43.0)$ and in the day $(20.2 \pm 6.8),(P=.24, P=0.73$, respectively) (Figure 5). Also, no significant difference was found in the distance between individuals in the day $(5.9 \pm 3.1 \mathrm{~cm})$ and the night $(5.7 \pm 2.5 \mathrm{~cm})(\mathrm{KW}=9,045, P=.08$, $n=261$ ) (Figure 6).

Most individuals had a test diameter between 70 and $120 \mathrm{~mm}(101.3 \pm 3.6 \mathrm{~mm})$ (Figure 7). The predominant size was between 90 and $100 \mathrm{~mm}$, which corresponds to adult size. The $\sim 70 \mathrm{~mm}$ size corresponds to large juveniles, and they had a different color 

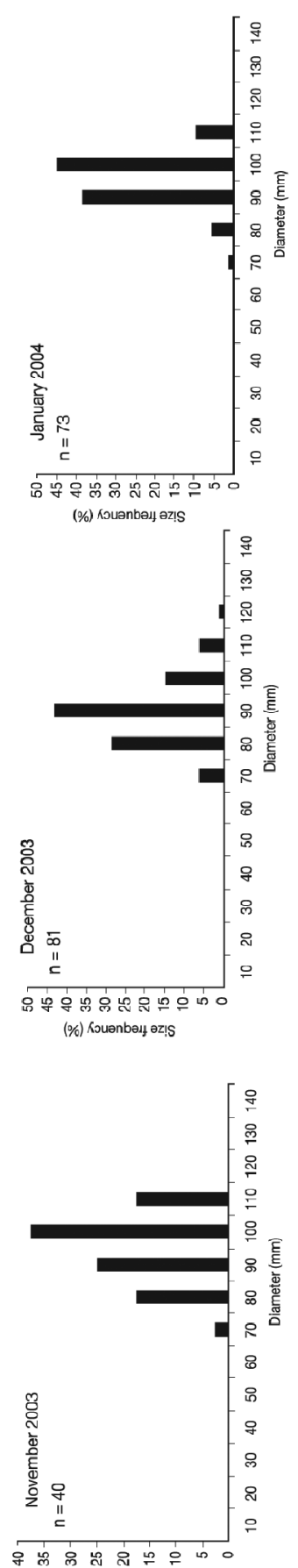

(\%) 1Ouenbed, az|S

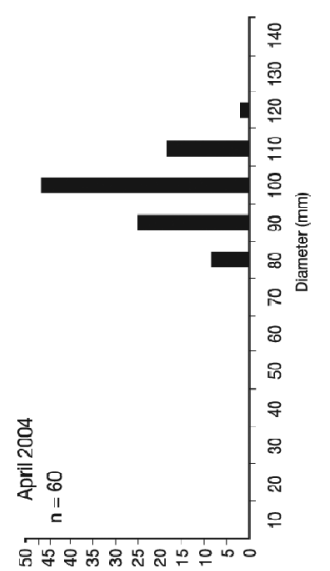

(\%)

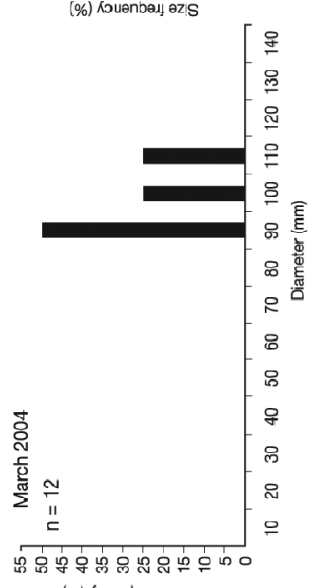

(\%) Kouənbey әz!S

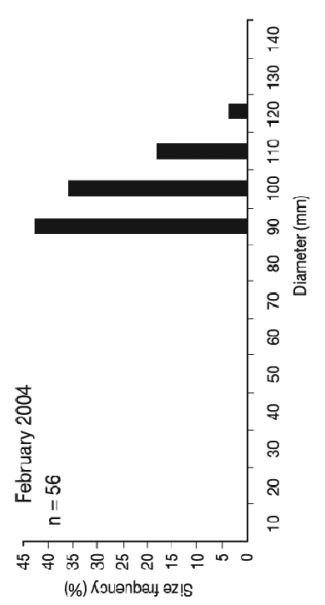

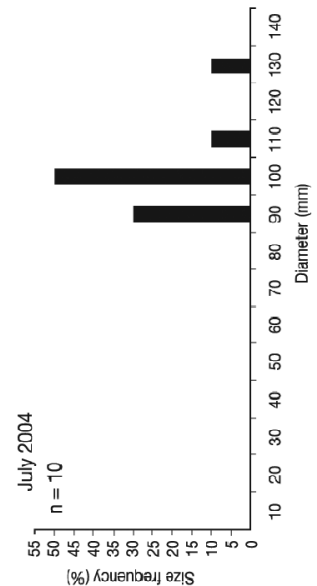

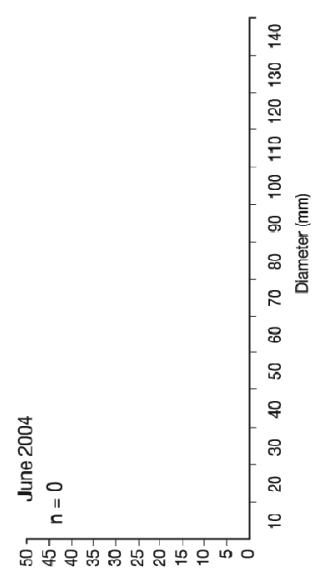

(\%) Kouenbaly ezIS

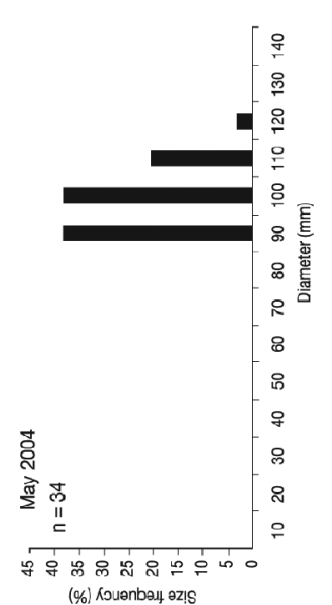

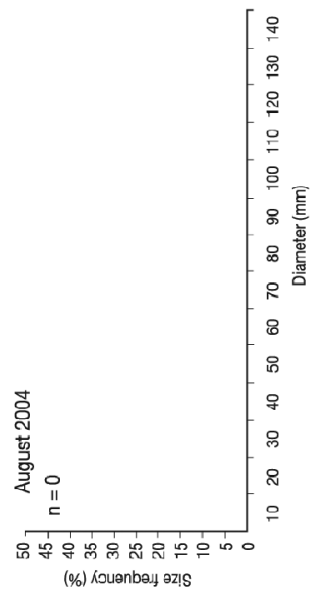


pattern than the adults. The sizes reported herein are within the range reported for the region (15-117 mm) (Clark 1923, 1940, 1948, Caso 1961, 1978, Lessios 1990). Clark (1948) pointed out, based on a series of collections from the eastern Pacific, that juveniles are between 17 and $35 \mathrm{~mm}$ and the adults range between 100 and $117 \mathrm{~mm}$.

\section{DISCUSSION}

Although aggregations of sea urchins could be associated with reproductive activities, in the majority of cases these aggregations appear to be in response to local environmental factors or involved in social interactions (Reese 1966). Three hypotheses have been proposed to explain the benefits of these aggregations: (1) food optimization, (2) resistance to predator attack, and (3) improvement of fertilization success at spawning (see references in Campbell et al. [2001]). In the case of tropical diadematids these aggregations represent social activities and do not seem to be simple responses to environmental limitations (Pearse and Arch 1969).

Pearse and Arch (1969) studied the aggregation behavior of Diadema setosum in Bougainville, Papua New Guinea, and determined that they are related to protection, instead of reproduction. They suggested that when urchins are too abundant to find shelter among rocks, individuals form aggregations for protection against predators. Moreover, when a few individuals within an aggregation are disturbed, they interact with others, and the whole aggregation moves away.

Astropyga pulvinata in Bahía Culebra may be aggregating for protection against predators because they presented behavior similar to that described by Pearse and Arch (1969). However, attacks on sea urchins were not observed, and broken tests were found only rarely. Also, aggregations appear during the upwelling season, when there is no evidence of an increase of predators. Because Astropyga spp. are detritivores (Mortensen 1940, De Ridder and Lawrence 1982), they may be exploiting the food resources produced during the upwelling season. The aggregations are probably due to a combination of both inter- actions (protection when abundant and food optimization). The aggregates are made up only of adult individuals, which have better protection due to their longer spines. Meanwhile, the juveniles protect themselves in caves or crevices on the rocky or reef areas.

During the upwelling season there is higher food availability, which is probably the reason the sea urchins come into shallow waters to feed. At that time of year, the thermocline is shallower (between 15 and $20 \mathrm{~m}$ ) with a higher zooplankton abundance (Bednarski and Morales-Ramírez 2004). The sea urchins may follow the change of the thermocline position and move to shallow water to feed, descending when the thermocline sinks at the end of the upwelling. Maurer et al. (1980) reported individuals of this species on the outer part of the Gulf of Nicoya, in Costa Rica, at $35 \mathrm{~m}$ depth. That depth corresponded with the thermocline zone, where the temperature was close to $20^{\circ} \mathrm{C}$ and the $\mathrm{PO}_{4}^{-3}$ concentration was $2 \mu \mathrm{M}$ (Epifanio et al. 1980). In Acapulco Bay (Pacific coast of Mexico), many aggregations of 5 to 30 individuals on rocky substrate were associated with the thermocline between 20 and $27 \mathrm{~m}$ depth (pers. obs., November 2005). This indicated that the adult behavior of Astropyga pulvinata is influenced by the behavior of the thermocline related to the disposition of food associated with it. A similar example of urchin aggregations to exploit food resources was observed in Japan, where Astropyga radiata aggregations reduced an eelgrass (Zostera maritima) patch (Bak and Nojima 1980), indicating migration to a food supply.

There is a possibility that these aggregations have a role in reproduction. Urchins could, for example, enhance fertilization by being aggregated during spawning. However, during the study spawning was not observed. Bauer (1976) found that Diadema antillarum in Florida aggregated during spawning months when sea temperatures are low, which worked as a triggering signal. In my study the focus was not on reproduction, but it should be considered in future research. Moreover, from size data (Figure 7) the observed phenomenon is not the result of local recruitment of recently metamorphosed sea 
TABLE 1

Organisms Associated with Astropyga pulvinata at Punta Flor, Bahía Culebra

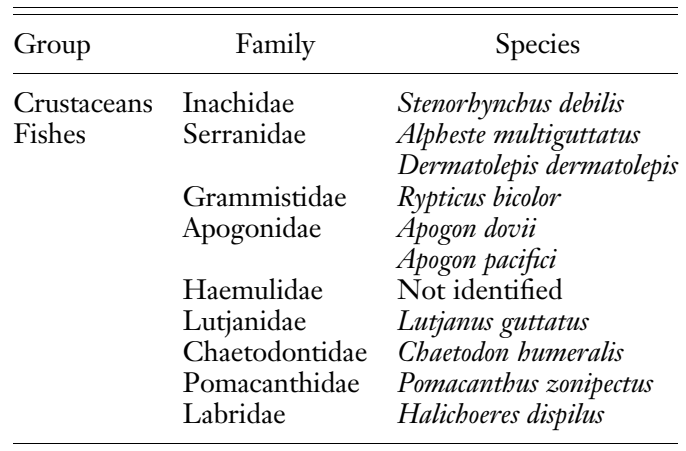

urchins but rather the immigration of adult individuals from elsewhere.

The diadematids have been recognized as refuges for several species of fishes, favoring the development of juvenile stages and in some cases adults and serving as biogenic structures that provide protection (Randall et al. 1964, Teytaud 1971, Hartney and Grorud 2002, Kolm and Berglund 2003). In my study, 10 species of fishes and one crab species (Stenorbynchus debilis) were observed associated with the Astropyga aggregations (Table 1). The fishes that were found most often were adults of Rypticus bicolor, which dig under the urchin spines, and two species of Apogon. The first species was observed close to the sand, under the spines of the urchin, and the apogonids were observed between the spines in high numbers. Apogon is commonly associated with diadematid aggregations (Kier and Grant 1965, Zann 1980, Moosleitner 2002, Kolm and Berglund 2003). Kolm and Berglund (2003) determined that densities of Pterapogon kauderni were positively correlated with aggregations of $\mathrm{Di}$ adema setosum in Sulawesi, indicating that the urchins formed an important habitat for the fish, which are under strong extraction pressure from the aquarium trade. Those authors concluded that these aggregations have an important conservation value for the fish because they provide a refuge. Based on the evidence from other regions of the world, the aggregations of Astropyga pulvinata in Bahía
Culebra act as a refuge too. This area of the country is subjected to much fish extraction for aquariums (Cortés 1996-1997, Ibarra 1996), so the urchins could have a high conservation value for several fish species in the region.

In the past few years, the local people of Bahía Culebra have seen a reduction of the populations of Astropyga pulvinata, which is being extracted for the aquarium trade. Consequently, it important to continue monitoring these populations and the impact of their disappearance on other species.

\section{ACKNOWLEDGMENTS}

I am grateful to Cindy Fernández, Davis Morera, Jaime Nivia, Eddy Gomez, Eva Salas, Mario Espinoza, Bernadette Bezy, Eleazar Ruiz, The Instituto Costarricense de Turismo, and Ecodesarrollo Papagayo for their collaboration. The manuscript was enriched by comments from Jorge Cortés, John Lawrence, John Pearse, and two anonymous reviewers.

\section{Literature Cited}

Bak, H., and P. Nojima. 1980. Immigration of tropical sea urchin, Astropyga radiata (Leske) in a temperate eelgrass, Zostera marina L., patch: Its feeding habit and grazing effect on the patch. Amakusa Mar. Biol. Lab. 5:153-169.

Barraza, J. E., and C. R. Hasbún. 2005. Los equinodermos (Echinodermata) de El Salvador. Rev. Biol. Trop. 53 (Suppl. 3): 139146.

Bauer, J. C. 1976. Growth, aggregation, and maturation in the echinoid, Diadema antillarum. Bull. Mar. Sci. 26:273-277.

Bednarski, M., and A. Morales-Ramírez. 2004. Composition, abundance and distribution of macrozooplancton in Culebra Bay, Gulf of Papagayo, Pacific coast of Costa Rica and its value as bioindicator of pollution. Rev. Biol. Trop. 52 (Suppl. 2): 105-118.

Birkeland, C. 1989. The influence of echinoderms on coral-reef communities. Pages 1-79 in M. Jangoux and J. M. Lawrence, 
eds. Echinoderm studies. Vol. 3. A. A. Balkema, Rotterdam.

Brenes, C. L., S. León, A. Gutiérrez, and G. Arroyo. 1990. Condiciones hidrográficas en la región de los "Papagayos." Rev. Geofís. 33:5-19.

Brusca, R. C. 1980. Common intertidal invertebrates of the Gulf of California. University of Arizona Press, Phoenix.

Campbell, A. C., S. Coppard, C. D'Abreo, and R. Tudor-Thomas. 2001. Escape and aggregation responses of three echinoderms to conspecific stimuli. Biol. Bull. (Woods Hole) 201:175-185.

Caso, M. E. 1961. Estado actual de los conocimientos acerca de los equinodermos de Mexico. Tesis Doctoral, Universidad Nacional Autónoma de México, México, D.F., México.

1978. Los equinoideos del Pacífico de México. Parte primera: Ordenes Cidaroidea y Aulodionta; Parte segunda: Ordenes Stiridonta y Camarodonta. Cent. Cienc. Mar Limnol. Univ. Nac. Auton. Méx., Publ. Esp. 1:1-244.

Clark, H. L. 1923. Echinoderms from lower California, with description of new species: Supplementary report. Bull. Am. Mus. Nat. Hist. 48:147-163.

. 1940. Eastern Pacific expeditions of the New York Zoological Society. XXI. Notes on echinoderms from the West Coast of Central America. Zoologica 25:331-352.

-1948. A report on the Echini of the warmer eastern Pacific, based on the collections of the Velero III. Allan Hancock Pac. Exped. 8:225-352.

Cortés, J. 1996-1997. Comunidades coralinas y arrecifes del Área de Conservación Guanacaste, Costa Rica. Rev. Biol. Trop. 44/ 45:623-625.

De Ridder, C., and J. H. Lawrence. 1982. Food and feeding mechanisms: Echinoidea. Pages 57-115 in M. Jangoux and J. M. Lawrence, eds. Echinoderm nutrition. A. A. Balkema, Rotterdam.

Epifanio, C., A. Voorhis, J. A. Vargas, D. Maurer, and M. M. Murillo. 1980. Physical-chemical survey. Pages 6-82 in
D. Maurer, C. Epifanio, and K. Price, eds. Ecological assessment of finfish and megabenthic invertebrates as indicators of natural and impacted habitats in the Gulf of Nicoya, Costa Rica. Progress Report of the 1979 International Sea Grant Program. University of Delaware, College of Marine Studies, Newark.

Espino-Barr, E., R. Cibrían, and A. García. 1996. Estructura y densidad de la población del erizo tinta Diadema mexicanum en el litoral rocoso del estado de Colima. Cienc. Pesq. 12:60-67.

Fischer, R. 1990. Biogenetic and nonbiogenetically determined morphologies of the Costa Rican Pacific coast. Z. Geomorphol. N.F. 34:313-321.

Glynn, P. W. 1988. El Niño warming, coral mortality and reef framework destruction by echinoid bioerosion in the eastern $\mathrm{Pa}$ cific. Galaxea 7:129-160.

Glynn, P. W., and G. Leyte-Morales. 1997. Coral reefs of Huatulco, West Mexico: Reef development in upwelling Gulf of Tehuantepec. Rev. Biol. Trop. 45:10331047.

Guzmán, H. M. 1988. Distribución y abundancia de organismos coralívoros en los arrecifes coralinos de la Isla del Caño, Costa Rica. Rev. Biol. Trop. 36:191-207.

Guzmán, H. M., and J. Cortés. 1992. Cocos Island (Pacific of Costa Rica) coral reefs after the 1982-83 El Niño disturbance. Rev. Biol. Trop. 40:309-324.

2007. Reef recovery 20 years after the 1982-1983 El Niño massive mortality. Mar. Biol. (Berl.) 151:401-411.

Hartney, K. B., and K. A. Grorud. 2002. The effect of sea urchins as biogenic structures on the local abundance of a temperate reef fish. Oecologia (Berl.) 131:506-513.

Herrera-Escalante, T., R. A. López-Pérez, and G. E. Leyte-Morales. 2005. Bioerosion caused by the sea urchin Diadema mexicanum (Echinodermata: Echinoidea) at Bahías de Huatulco, western Mexico. Rev. Biol. Trop. 53 (Suppl. 3): 263-273.

Hickman, C. P., Jr. 1998. A field guide to sea stars and other echinoderms of Galápagos. Sugar Spring Press, Lexington, Virginia. 
Hooker, Y., F. A. Solís-Marín, and M. Lleellish. 2005. Equinodermos de las Islas Lobos de Afuera (Lambayeque, Perú). Rev. Peru. Biol. 12:77-82.

Hyman, L. H. 1955. The invertebrates: Echinodermata. McGraw-Hill, New York.

Ibarra, E. 1996. El valor de uso del paisaje submarino en el Golfo de Papagayo. Licenciatura Economía, Fac. Ciencias Económicas, Univ. Costa Rica, San Pedro, San José.

Jiménez, C. 2001. Arrecifes y ambientes coralinos de Bahía Culebra, Pacífico de Costa Rica: Aspectos biológicos, económicorecreativos y de manejo. Rev. Biol. Trop. 49 (Suppl. 2): 215-231.

Kennedy, B., and J. S. Pearse. 1975. Lunar synchronization of the monthly reproductive rhythm in the sea urchin Centrostephanus coronatus Verrill. J. Exp. Mar. Biol. Ecol. 17:323-331.

Kier, P. M., and R. E. Grant. 1965. Echinoid distribution and habits, Key Largo Coral Reef Preserve, Florida. Smithson. Misc. Collect. 149:1-68.

Kolm, N., and A. Berglund. 2003. Wild populations of a reef fish suffer from the "nondestructive" aquarium trade fishery. Conserv. Biol. 17:910-914.

Lessios, H. A. 1981. Reproductive periodicity of the echinoid Diadema and Echinometra on the two coasts of Panama. J. Exp. Mar. Biol. Ecol. 50:47-61.

- 1990. Adaptation and phylogeny as determinants of egg size in echinoderms from the two sides of the Isthmus of Panama. Am. Nat. 135:1-13.

. 2005. Echinoids of the Pacific waters of Panama: Status of knowledge and new records. Rev. Biol. Trop. 53 (Suppl. 3): 147-170.

Lessios, H. A., B. D. Kessing, and J. S. Pearse. 2001. Population structure and speciation in tropical seas: Global phylogeography of the sea urchin Diadema. Evolution 55:955-975.

Maurer, D., C. Epifanio, K. Price, J. A. Vargas, M. M. Murillo, H. Dean, S. Howe, and R. Monahan. 1980. Megabenthic invertebrate survey. Pages 145-306 in D.
Maurer, C. Epifanio, and K. Price, eds. Ecological assessment of finfish and megabenthic invertebrates as indicators of natural and impacted habitats in the Gulf of Nicoya, Costa Rica. Progress Report of the 1979 International Sea Grant Program. University of Delaware, Newark.

Moosleitner, H. 2002. Kardinalbarsche: Interessante arten der familie Apogonidae aus dem Roten Meer. Das Aquarium 393:56-59.

Mortensen, T. 1940. A monograph of the Echinoidea. III (1). C. A. Reitzel, Copenhagen.

Neira, R., and J. R. Cantera. 2005. Composición taxonómica y distribución de las asociaciones de equinodermos en los ecosistemas litorales del Pacífico Colombiano. Rev. Biol. Trop. 53 (Suppl. 3): 195-206.

Pearse, J., and S. W. Arch. 1969. The aggregation behavior of Diadema (Echinodermata, Echinoidea). Micronesia 5:165-171.

Randall, J., R. E. Schroeder, and W. A. Starck. 1964. Notes on the biology of the echinoid Diadema antillarum. Caribb. J. Sci. 4:421-433.

Reese, E. S. 1966. The complex behavior of echinoderms. Pages 561-613 in R. A. Boolootian, ed. Physiology of Echinodermata. Interscience, New York.

SAS Institute. 2001. JMPin 4.0. SAS Institute, Cary, North Carolina.

Solís-Marín, F. A., A. Laguarda-Figueras, A. Durán-González, C. G. Ahearn, and J. Torres-Vega. 2005. Equinodermos (Echinodermata) del Golfo de California, México. Rev. Biol. Trop. 53 (Suppl. 3): 123-137.

Strickland, J. D. H., and T. R. Parsons. 1972. A practical handbook of seawater analysis. Fish. Res. Board Can. Bull. 167.

Systat Software. 1998. Systat 8.0. Systat Software Inc., San Jose, California.

Teytaud, A. R. 1971. Food habits of the goby, Ginsburgellus novemlineatus, and the clingfish, Arcos rubiginosus, associated with echinoids in the Virgin Islands. Caribb. J. Sci. 11:41-45.

Toro-Farmer, G., J. R. Cantera, E. LondoñoCruz, C. Orozco, and R. Neira. 2004. Patrones de distribución y tasa de bioerosión 
del erizo Centrostephanus coronatus (Diadematoida: Diadematidae), en el arrecife de Playa Blanca, Pacífico colombiano. Rev. Biol. Trop. 52:67-76.

Vance, R. R. 1979. Effects of grazing by the sea urchin, Centrostephanus coronatus, on prey community composition. Ecology 60:537-546.

Zann, L. P. 1980. Symbionts of sea urchins. Pages 247-254 in L. P. Zann, ed. Living together in the sea. TFH Publications, New Jersey. 